\title{
Immunohistochemical and Electron Microscopical Detection of Parafollicular (C) Cells in Equine Parathyroid Glands
}

\author{
Nobuhiko TANIMURA, Susumu TATEYAMA, Dai NOSAKA, Yasuo MORITOMO ${ }^{1)}$, and \\ Ryoji YAMAGUCHI \\ Department of Veterinary Pathology, Faculty of Agriculture, Miyazaki University, 77lo Oazakumano, Miyazaki \\ 889-21, and ')Faculty of Agriculture, Kyushu Tokai University, Asogun, Kumamoto 869-14. Japan
}

(Received 26 April 1985/Accepted 14 October 1985)

\begin{abstract}
Fifty-six parathyroid glands from 41 horses were examined with hematoxylin-eosin staining and immunoperoxidase method using rabbit anti-human calcitonin antiserum and an electron microscope. $\mathrm{C}$ cells filled with immunoreactive secretory granules and distinguished from nonreactive parathyroid cells were found in 42 cases of the equine parathyroid glands. The morphological characteristics and the sensitivity to the anti-calcitonin antiserum of $\mathrm{C}$ cells in the equine parathyroid glands were almost identical with those of $\mathrm{C}$ cells in the equine thyroid glands. The parathyroid $\mathrm{C}$ cells were much more eosinophilic than the chief cells and the water clear cells in hematoxylin-eosin staining. The ultrastructural features of $\mathrm{C}$ cells were apparently different from those of the so-called oxyphil cells. They possessed abundant secretory granules of various sizes and were separated from the stroma by a basement membrane together with other parathyroid cells. Desmosomes were found at sites attached to neighboring cells, and half-desmosomes at sites attached to a basement membrane. No transitional cells between the oxyphil cells and the $\mathrm{C}$ cells were observed. This study showed that the immunoreactive $\mathrm{C}$ cells in the equine parathyroid glands appeared more frequently in parathyroids fused with thyroids than in ones freed from thyroids. No apparent differences could be observed in the frequency of occurrence of $\mathrm{C}$ cells owing to breed, age, and sex of the horses.-KEY wORDS: calcitonin, equine parathyroid gland, oxyphil cell, parafollicular $(\mathrm{C})$ cell.
\end{abstract}

Jpn. J. Vet. Sci. 48(1): 45-52, 1986

It has been reported that in some mammalian species, e.g., rabbit, cat goat, dog [5-7], and house shrew [8], $\mathrm{C}$ cells are present not only in the thyroid gland but also in the parathyroid gland. However, there appears to be no such description of the parathyroid gland in the horse. In the present study, the immunoperoxidase method using the specific antiserum against human calcitonin was carried out in order to determine whether or not the $C$ cells are also distributed in the equine parathyroid gland. Furthermore, the structure of the $\mathrm{C}$ cells in the equine parathyroid gland was investigated by light and electron microscopy.

\section{MATERIALS AND METHODS}

Fifty-six parathyroid glands from 41 horses were collected at the Miyakonojo (Miyazaki Prefecture) and Kumamoto (Kumamoto Prefecture) slaughterhouses (Table 1).

For light microscopy, these parathyroid glands were fixed in neutral buffered $10 \%$ formalin for 2-3 weeks. The specimens were embedded in paraffin and cut at $4 \mu \mathrm{m}$ thickness. Deparaffinized sections were stained with hematoxylin-eosin (HE) and an unlabeled antibody-enzyme method using peroxidase-antiperoxidase procedure. For immunohistochemical staining, the sections were processed with a sequence of solutions from a commercial kit (Ortho Diagnostic Systems Inc., USA). Reaction products were developed with 3,3'-diaminobenzidine tetrahydrochloride and hydrogen peroxide. Hematoxylin was used as a counter stain. Control sections were incubated with non-immune 
Table 1 .

\begin{tabular}{|c|c|c|c|c|c|}
\hline Group ${ }^{a)}$ & $\begin{array}{l}\text { Case } \\
\text { No. }\end{array}$ & Breed $^{\text {b) }}$ & $\begin{array}{c}\text { Age } \\
\text { (Years) }\end{array}$ & $\operatorname{Sex}{ }^{c)}$ & $\begin{array}{l}\text { Occurrence } \\
\text { of C cells d) }\end{array}$ \\
\hline Group 1 & $\begin{array}{r}1 \\
2 \\
3 \\
4 \\
5 \\
6 \\
7 \\
8 \\
9 \\
10 \\
11 \\
12 \\
13 \\
14 \\
15 \\
16 \\
17 \\
18 \\
19 \\
20 \\
21 \\
22\end{array}$ & $\begin{array}{l}\mathrm{H} \\
\mathrm{H} \\
\mathrm{H} \\
\mathrm{H} \\
\mathrm{H} \\
\mathrm{L} \\
\mathrm{H} \\
\mathrm{H} \\
\mathrm{H} \\
\mathrm{H} \\
\mathrm{L} \\
\mathrm{L} \\
\mathrm{L} \\
\mathrm{L} \\
\mathrm{L} \\
\mathrm{H} \\
\mathrm{H} \\
\mathrm{L} \\
\mathrm{H} \\
\mathrm{L} \\
\mathrm{H} \\
\mathrm{H}\end{array}$ & $\begin{array}{r}3 \\
3 \\
3 \\
3 \\
3 \\
4 \\
4 \\
5 \\
5 \\
5 \\
5 \\
5 \\
5 \\
5 \\
6 \\
8 \\
9 \\
10 \\
10 \\
10 \\
10 \\
10\end{array}$ & $\begin{array}{l}G \\
- \\
M \\
G \\
G \\
\\
F \\
G \\
G \\
F \\
F \\
F \\
F \\
F \\
F \\
G \\
\\
\\
F \\
F \\
F \\
F\end{array}$ & $\begin{array}{l}+ \\
+ \\
- \\
- \\
- \\
+ \\
- \\
+ \\
+ \\
+ \\
- \\
+ \\
- \\
- \\
+ \\
- \\
+ \\
+ \\
+ \\
+ \\
- \\
-\end{array}$ \\
\hline Group 2 & $\begin{array}{l}23 \\
24 \\
25 \\
26 \\
27\end{array}$ & $\begin{array}{l}\mathrm{H} \\
\mathrm{H} \\
\mathrm{H} \\
\mathrm{H} \\
\mathrm{H}\end{array}$ & $\begin{array}{r}4 \\
5 \\
7 \\
10 \\
10\end{array}$ & $\begin{array}{l}F \\
F \\
F \\
F \\
F\end{array}$ & $\begin{array}{l}+ \\
+ \\
+ \\
- \\
+\end{array}$ \\
\hline Group 3 & $\begin{array}{l}28 \\
29 \\
30 \\
31 \\
32 \\
33 \\
34 \\
35 \\
36 \\
37 \\
38 \\
39 \\
40 \\
41 \\
42 \\
43 \\
44 \\
45 \\
46 \\
47 \\
48 \\
49 \\
50 \\
51 \\
52 \\
53 \\
54 \\
55 \\
56\end{array}$ & $\begin{array}{l}L \\
H \\
H \\
H \\
H \\
H \\
H \\
H \\
H \\
H \\
H \\
H \\
\text { D } \\
H \\
H \\
H \\
H \\
L \\
H \\
L \\
H \\
H \\
H \\
H \\
H \\
H \\
H \\
H \\
- \\
- \\
- \\
-\end{array}$ & $\begin{array}{r}2 \\
3 \\
3 \\
3 \\
3 \\
3 \\
3 \\
3 \\
3 \\
3 \\
3 \\
4 \\
4 \\
4 \\
5 \\
5 \\
5 \\
6 \\
6 \\
6 \\
6 \\
7 \\
7 \\
7 \\
7 \\
7 \\
8 \\
8 \\
9 \\
9 \\
9 \\
10 \\
10\end{array}$ & $\begin{array}{l}F \\
M \\
M \\
\\
\\
F \\
G \\
G \\
G \\
F \\
F \\
G \\
G \\
G \\
G \\
F \\
F \\
F \\
F \\
G \\
G \\
F \\
- \\
\\
F \\
F \\
F \\
-\end{array}$ & $\begin{array}{l}+ \\
+ \\
+ \\
+ \\
+ \\
+ \\
+ \\
+ \\
+ \\
+ \\
+ \\
+ \\
+ \\
+ \\
+ \\
+ \\
+ \\
+ \\
+ \\
+ \\
+ \\
+ \\
+ \\
+ \\
+ \\
+ \\
+\end{array}$ \\
\hline
\end{tabular}

a) See the text.

b) $\mathrm{H}=$ Heavy breed, $\mathrm{L}=\mathrm{Light}$ breed, $-=$ unknown .

c) $\mathrm{G}=$ Gelding, $\mathrm{M}=$ Male, $\mathrm{F}=$ Female, $-=$ unknown.

d) $+=$ positive, $-=$ negative. rabbit serum in place of rabbit anti-human calcitonin antiserum.

For electron microscopy, the parathyroid glands were fixed in $3 \%$ glutaraldehyde in 0.1 $\mathrm{M}$ cacodylate buffer, $\mathrm{pH} 7.4$, for 2 hours and postfixed in $1 \%$ osmium tetroxide in $0.1 \mathrm{M}$

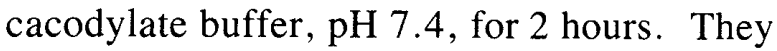
were then dehydrated in graded alcohols and embedded in Spurr's resin. Ultrathin sections were stained with uranyl acetate and lead citrate and examined with a Hitachi 125 DS electron microscope.

\section{RESULTS}

The $\mathrm{C}$ cells in the equine thyroid glands were densely stained with anti-human calcitonin antiserum (Fig. 1) [9], but no reaction products were observed when the rabbit antihuman calcitonin antiserum was replaced with the serum of non-immunized rabbits. Thus, there seems to be the cross-reaction between human and horse calcitonin $[\hat{\alpha}, 6]$.

The $\mathrm{C}$ cells in the equine parathyroid glands were observed filled with reaction products after the immunoperoxidase staining with anti-human calcitonin antiserum. They were easily distinguished from non-reactive parathyroid cells. C cells showed polymorphism in their cell morphology, and often possessed cytoplasmic protrusions. They reacted with various intensity to anti-human calcitonin antiserum (Fig. 2). The C cells appeared as a single cell or as a small group of cells among the parathyroid cells. They occasionally formed some of the large aggregation (Fig. 3). These morphological characteristics of the $\mathrm{C}$ cells in the equine parathyroid glands were almost identical with those of the $\mathrm{C}$ cells in the equine thyroid glands. The $\mathrm{C}$ cels in the equine parathyroid glands were distributed not only among the chief cells but also among the clusters of water clear cells (Fig. 4).

When HE staining was applied to sections of the equine parathyroid glands, eosinophilic 


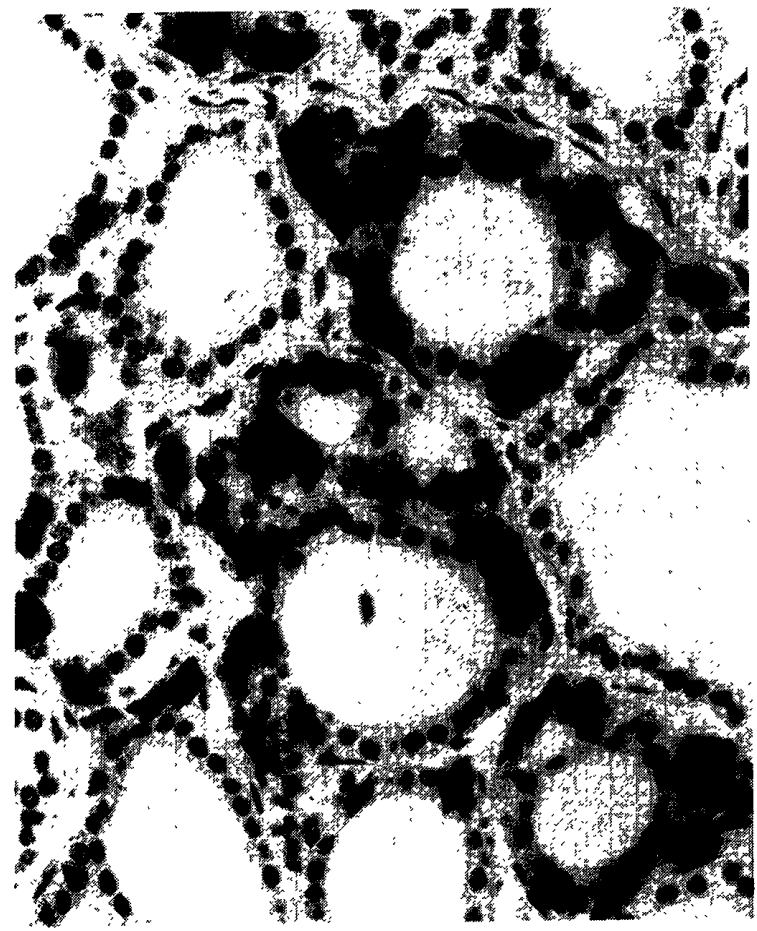

Fig. 1. Equine thyroid gland stained by the immunoperoxidase method using anti-human calcitonin antiserum. The crossreactions of equine $\mathrm{C}$ cells are represented. These cells are scattered in parafollicular positions. Counter-stained with hematoxylin. Case No. 32. $\times 300$.

cells were found among the parathyroid cells. When serial sections were stained with $\mathrm{HE}$ and immunohistochemistry, some of the eosinophilic cells corresponded to the positive cells for anti-human calcitonin antiserum (Fig. 5-a, b). The eosinophilic cells which were unreactive for anti-human calcitonin antiserum generally had swollen cytoplasms and comprised small groups interspersed among chief cells (Fig. 5-a, b).

The equine $\mathrm{C}$ cells in parathyroid glands viewed under an electron microscope were characterized by the possession of abundant secretory granules, which were electron dense, spherical or oval in shape with a diameter of 170 to $340 \mathrm{~nm}$ (Fig. 6). Desmosomes were observed between $\mathrm{C}$ cells and adjacent parathyroid chief cells (Fig. 7). They were also detected between adjacent $\mathrm{C}$ cells. Half desmosomes were also found in the $\mathrm{C}$ cells along the basement membrane

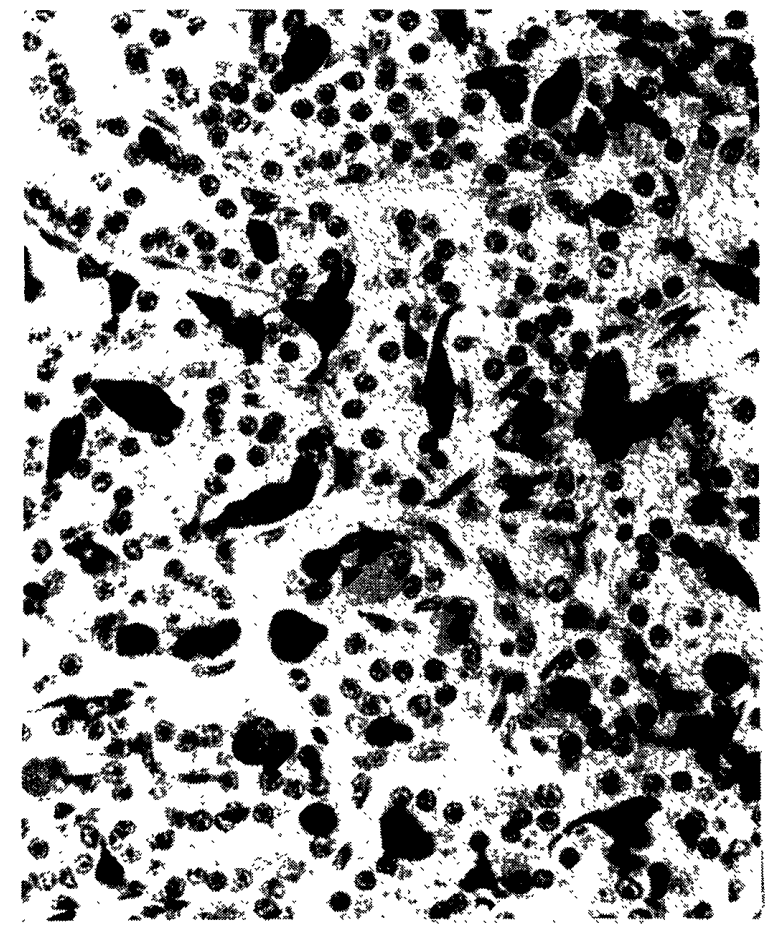

Fig. 2. Equine parathyroid gland stained by the immunoperoxidase method using anti-human calcitonin antiserum. Some $\mathrm{C}$ cells possess cytoplasmic protrusions. Counter-stained with hematoxylin. Case No. 10. $\times 300$.

(Fig. 8).

Cytoplasm of oxyphil cell observed among parathyroid chief cells was filled with numerous, usually rod-shaped or spherical, mitochondria. A few electron-dense bodies of variable sizes and shapes were found in the perinuclear region and at the periphery of the cell (Fig. 9). No intermediate type of cells between the oxyphil cells and the $\mathrm{C}$ cells were observed.

As a result, immunoreactive $\mathrm{C}$ cells were found in 42 out of 56 cases (75\%) of equine parathyroid glands, although only single section of each case was examined. In order to elucidate the relationship between the frequency of occurrence of the $C$ cells and the location of the parathyroid glands, they were classified into 3 groups, according to the following criteria:

Group 1: In parathyroids freed from the thyroid parenchyma, 12 out of 22 cases (55\%) 


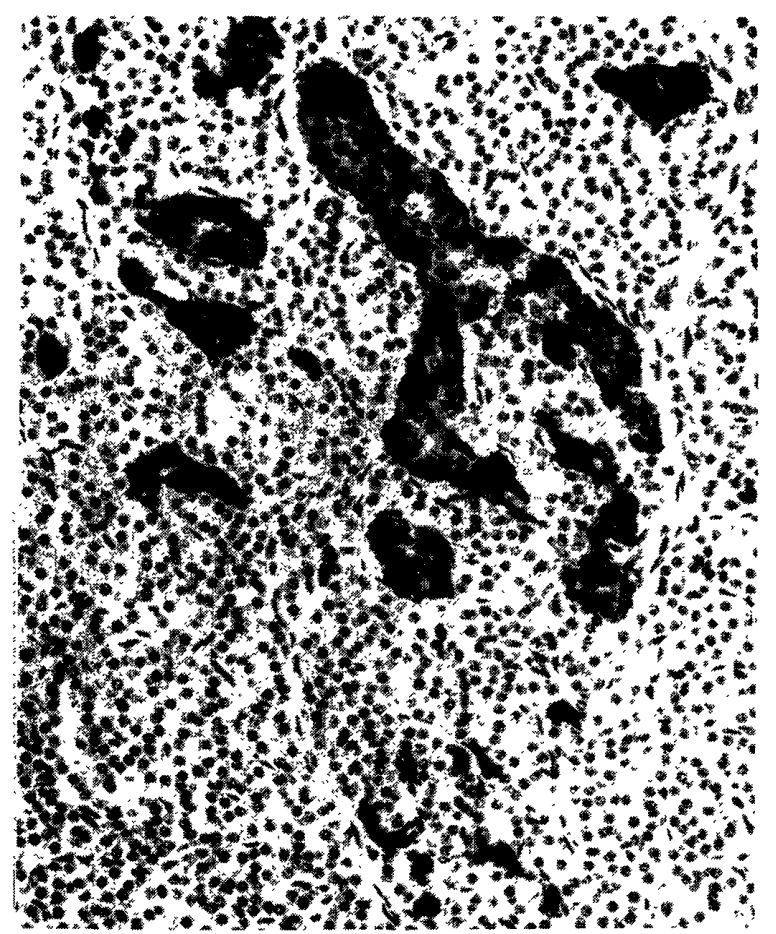

Fig. 3. Immunoreactive $\mathrm{C}$ cells' clusters showing large aggregations. Counter-stained with hematoxylin. Case No. $41 . \times 160$.

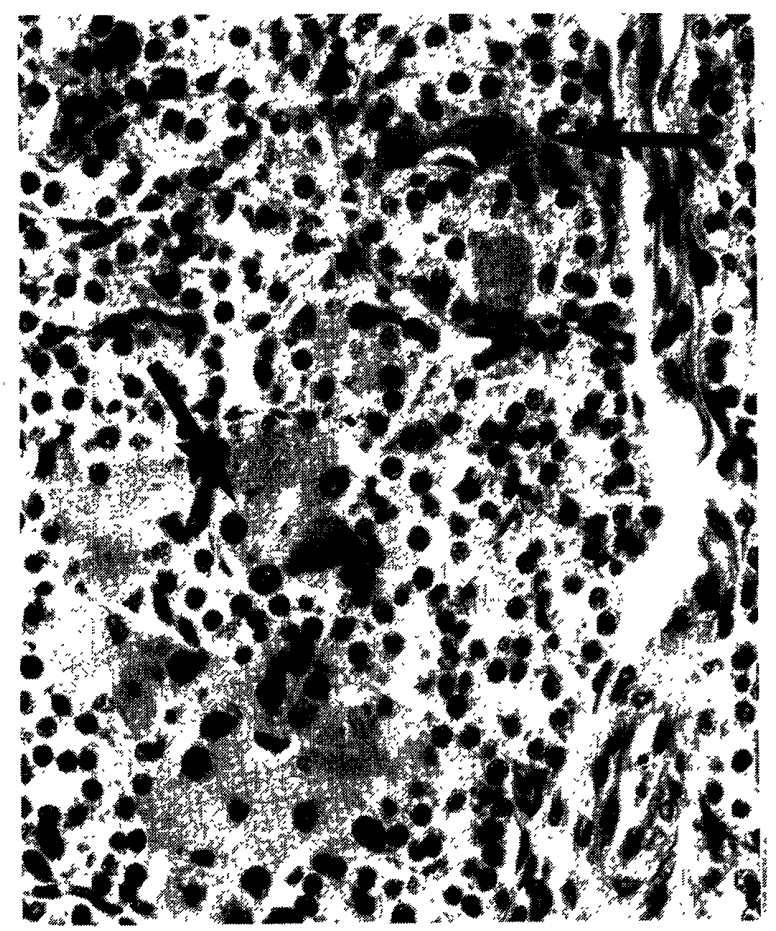

Fig. 5a. Neighboring serial sections of the parathyroid gland. Case No. 18

a. Eosinophilic cells are distributed among parathyroid cells. Arrows indicate the same cells as those shown in $b$. HE staining. $\times 300$

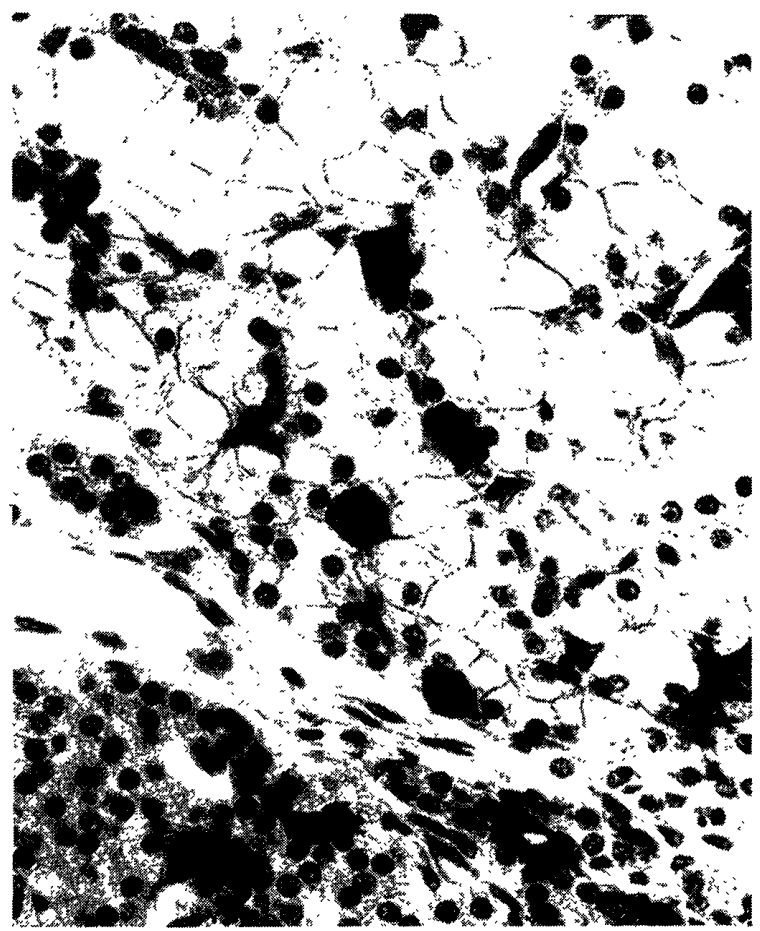

Fig. 4. Immunoreactive $\mathrm{C}$ cells distributed among the clusters of water clear cells. Counter-stained with hematoxylin. Case No. $30 . \times 300$.

-

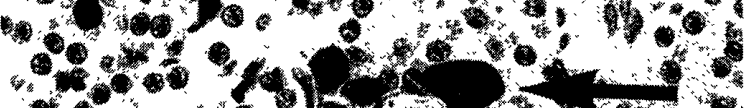

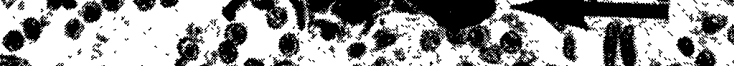

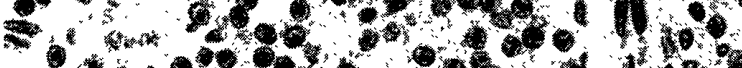

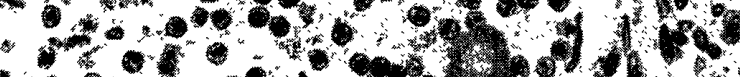

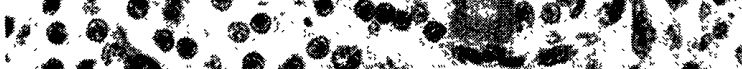

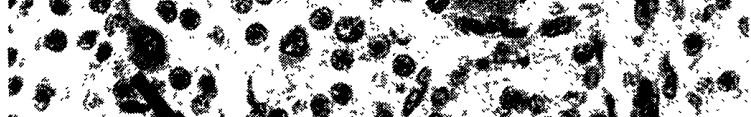

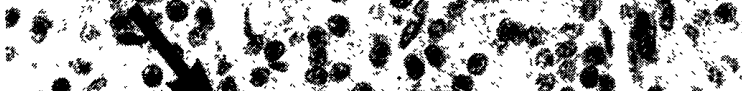

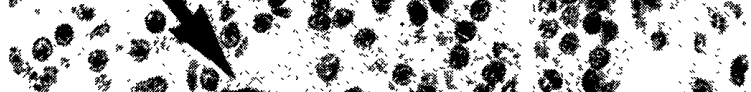

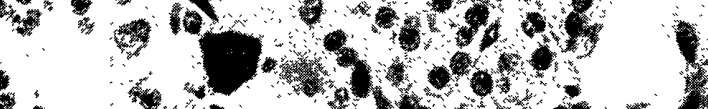

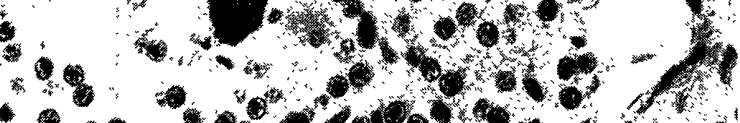

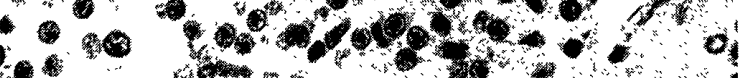

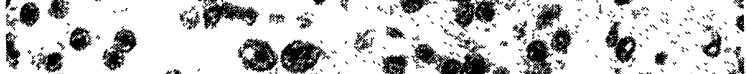
60\%

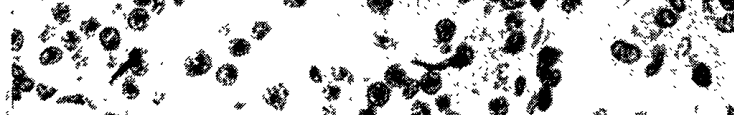

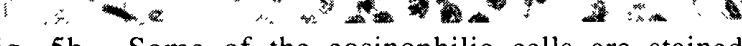

Fig. 5b. Some of the eosinophilic cells are stained positively with anti-human calcitonin antiserum. Arrows indicate the same cells as those shown in a. Counter-stained with hematoxylin. $\times 300$. 


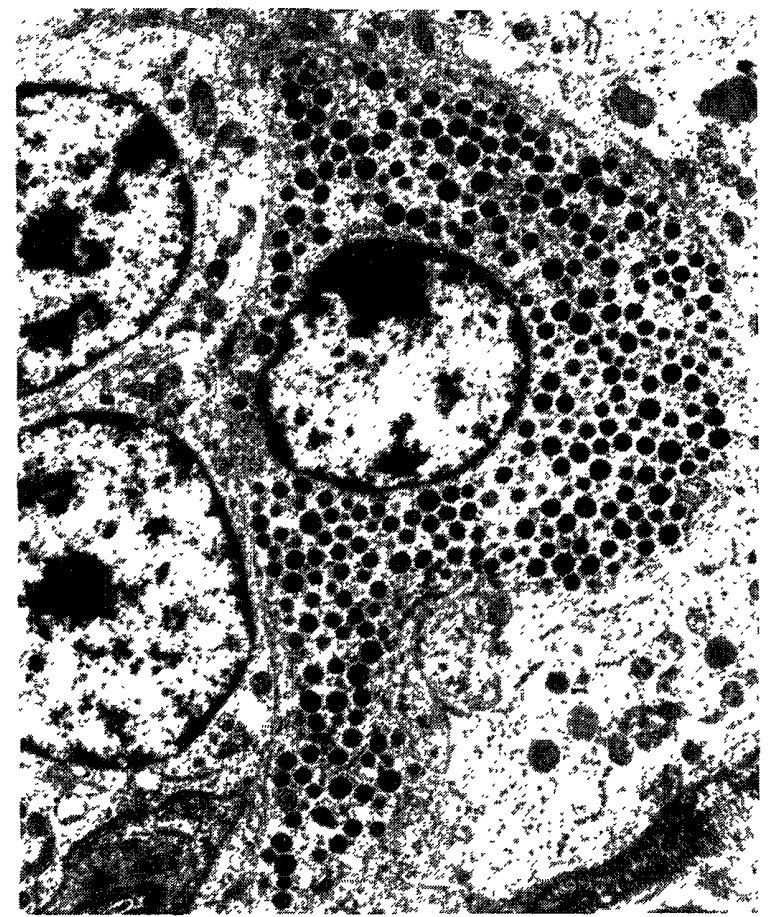

Fig. 6. C cell of the equine parathyroid gland. Abundant secretory granules ( 170 to $340 \mathrm{~nm}$ in diameter) are packed in the cytoplasm. Case No. 10. $\times 6,200$.

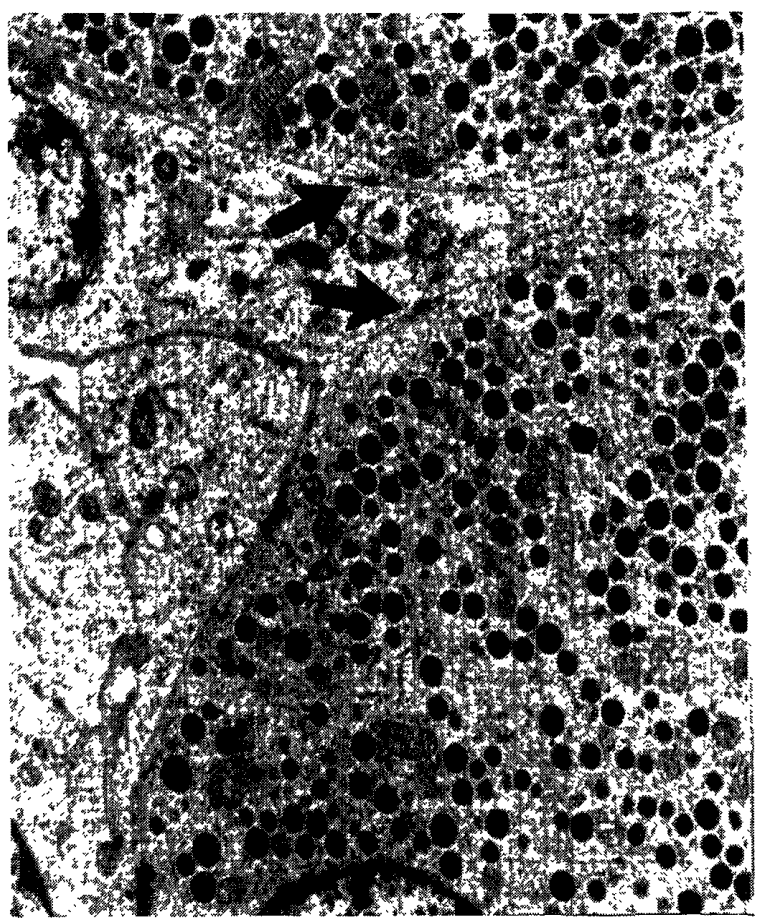

Fig. 7. Desmosomes (arrow) seen between the $\mathrm{C}$ cell and the adjacent parathyroid chief cell. Case No. 10. $\times 7,900$.

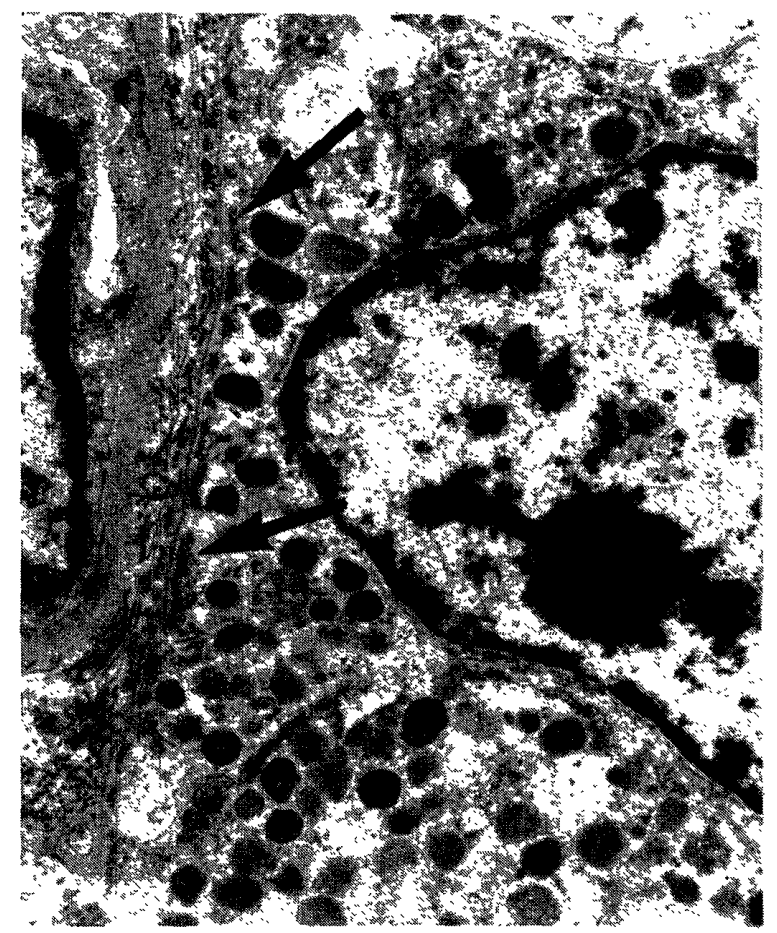

Fig. 8. Half desmosomes (arrow) seen in the $\mathrm{C}$ cell along the basement membrane. Case No. 10. $\times 12,400$.

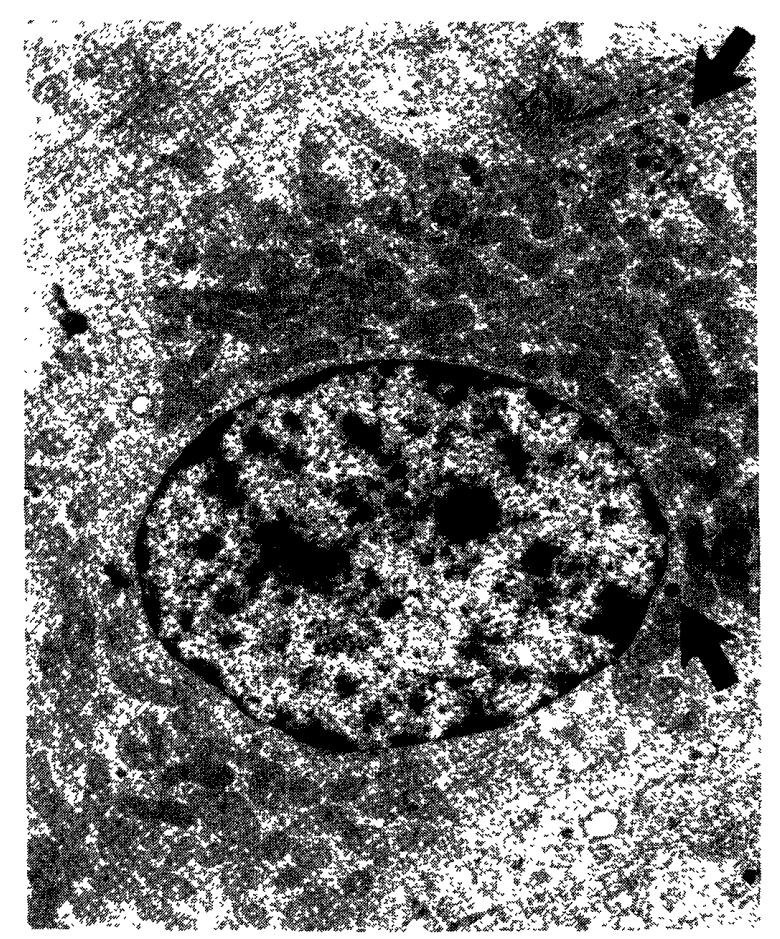

Fig. 9. Oxyphil cell of the equine parathyroid gland. The cytoplasm is filled with numerous mitochondria and contains a few dense bodies (arrow). Case No. 26. $\times 7,200$. 


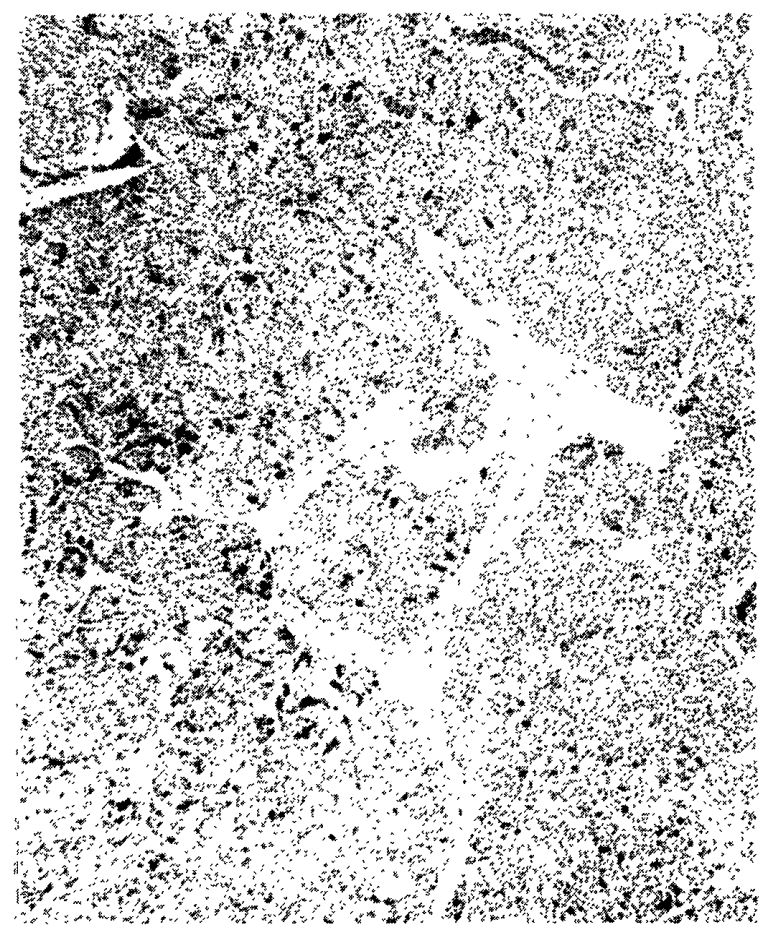

Fig. 10. A large number of immunoreactive $\mathrm{C}$ cells distributed among parathyroid cells. Counter-stained with hematoxylin. Case No. 10. Group 1. $\times 50$.

contained C cells.

Group 2: In parathyroids attached to the thyroid parenchyma with thick connective tissue, 4 out of 5 cases $(80 \%)$ contained C cells. Since this group had only a few cases, the frequency of occurrence of $\mathrm{C}$ cells was uncertain.

Group 3: In parathyroids fused with the thyroid parenchyma, 26 out of 29 cases (90\%) contained $\mathrm{C}$ cells (Table 1). In each group, the number of $\mathrm{C}$ cells in the parathyroid parenchyma was different from case to case. That is, some cases contained a relatively large number of $\mathrm{C}$ cells, while others contained a relatively small number (Fig. 10, 11). In addition, the equine parathyroid glands which contained $\mathrm{C}$ cells were classified according to the type of breed (heavy breed 30/39 cases, light breed $9 / 12$ cases, unknown $3 / 5$ cases), age and sex (male 2/3 cases, female 17/27 cases, gelding 11/14 cases, unknown 12/12 cases). There was no apparent difference in the frequency of occurrence of the $C$ cells due to any of these classifications.

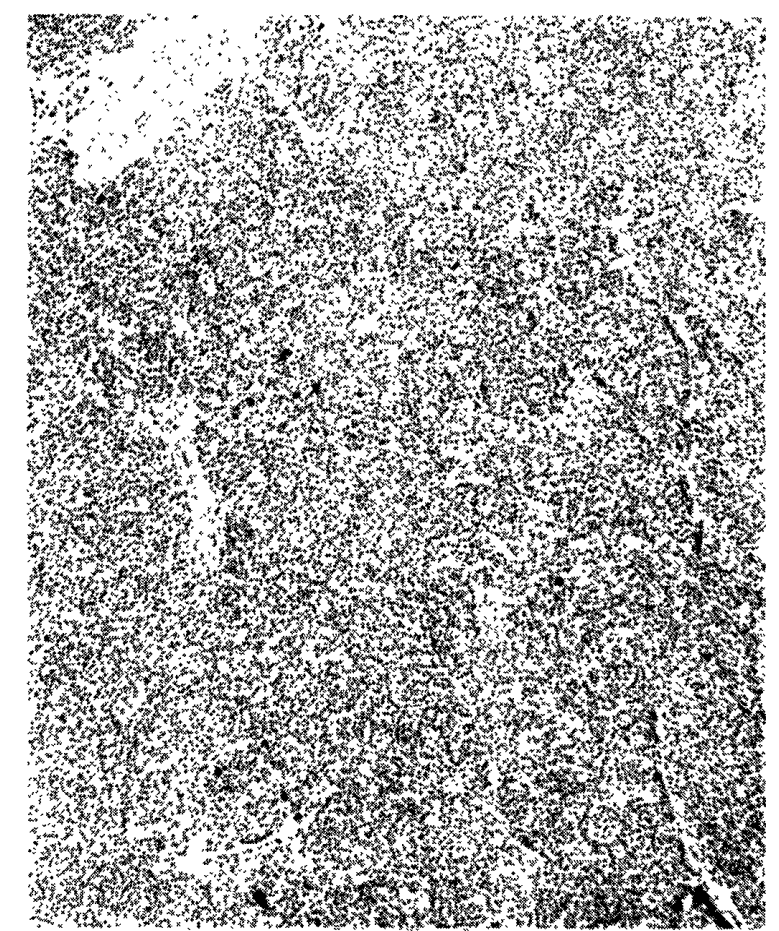

Fig. 11. A small number of immunoreactive $\mathrm{C}$ cells distributed among parathyroid cells. Counter-stained with hematoxylin. Case No. 15. Group 1: $\times 50$.

\section{DISCUSSION}

From the present study, it is clear that the $\mathrm{C}$ cells were scattered within not only the thyroid gland but also the parathyroid gland of the horse. The $\mathrm{C}$ cells in the equine parathyroid gland were characterized with the same cytological features $[10,11]$ and immunoreactions to anti-human calcitonin antiserum [9] as the cells in the equine thyroid gland. Since calcitonin secreted by $C$ cells is one of the major hormones to maintain calcium homeostasis [3], it should be examined whether or not the $\mathrm{C}$ cells in parathyroid show the same reaction as the $\mathrm{C}$ cells in thyroid to control the concentration of blood calcium of the horse.

Since some of the eosinophilic cells in the equine parathyroid glands were stained densely with anti-human calcitonin antiserum, it is considered that these eosinophilic cells viewed under the light microscope were not the so-called 'oxyphil cells' filled with numerous mitochondria seen in the electron 
microscopy, but $\mathrm{C}$ cells containing abundant secretory granules. The eosinophilic cells stained weakly with anti-calcitonin antiserum may be $\mathrm{C}$ cells having less secretory granules than mature $\mathrm{C}$ cells. The eosinophilic cells stained negatively with anti-calcitonin antiserum may be true oxyphil cells. Although the affinity for eosin of eosinophilic cells in the equine parathyroid glands varied from cell to cell, no discriminative value could be found for distinguishing $\mathrm{C}$ cells from non- $\mathrm{C}$ cells. Further investigation is needed to confirm the immunoreactivity of eosinopilic cells by an immunoperoxidase method using the antiserum against the specific mitochondrial respiratory enzyme, cytochrome $\mathrm{c}$ oxidase [1].

Fujimoto et al. [4] suggested that oxyphil cells in the equine parathyroid glands were formed from chief cells by way of 'transitional oxyphil cells' characterized by numerous microbodies having a medium grade of electron density. They believed that the microbodies represented the precursory structures of the mitochondria. However, in the present study, no transitional oxyphil cells having numerous microbodies regarded as the precursory structures of the mitochondria could be found in any of the equine parathyroid glands examined by electron microscopy. Dense bodies similar to those we found in the oxyphil cell of the equine parathyroid gland have been described previously by Fujimoto et al. [4], who regarded them as the secretory granules of parathyroid hormone. The absence of the transitional cells between the $\mathrm{C}$ cells and the oxyphil cells in equine parathyroid glands examined by electron microscopy supports the hypothesis that the oxyphil cells are derived from the chief cells $[3,4]$.

It is well known that $\mathrm{C}$ cells are derived from ultimobranchial bodies, which move into thyroid parenchyma to disperse as thyroid $C$ cells [5-7]. It seemed likely that the frequency of occurrence of the $\mathrm{C}$ cells in equine parathyroid glands was higher in parathyroids fused with the thyroid parenchyma than in ones freed from the thyroid parenchyma. Hence, it is considered that the ultimobranchial bodies almost constantly invade the equine parathyroids fused with the thyroid parenchyma, while invasion into equine parathyroids freed from the thyroid parenchyma is occasional. In addition, there could be the possibility that during early fetal period, the ultimobranchial bodies have much more chances to move into the nearby parathyroid anlages than the remote ones and that the formers fuse with the thyroid parenchyma, while the latters do not.

ACKNOWLEDGEMENTS. The authors wish to thank the meat inspectors of the Miyakonojo and Kumamoto Abattoirs for providing the materials used.

\section{REFERENCES}

1. Bedetti, C. D., Dekker, A., and Watson, C. G. 1984. Functioning oxyphil cell adenoma of the parathyroid gland: A clinicopathologic study of ten patients with hyperparathyroidism. Hum. Pathol. 15: 1121-1126.

2. Blähser, S. 1978. Immunocytochemical demonstration of calcitonin-containing $\mathrm{C}$-cells in the thyroid glands of different mammals. Cell Tissue Res. 186: 551-558.

3. Capen, C. C. 1975. Functional and fine structural relationships of parathyroid glands. Adv. Vet. Sci. Comp. Med. 19: 249-286.

4. Fujimoto, Y., Matsukawa, K., Inubushi, H., Nakamatsu, M., Satoh, H., and Yamagiwa, S. 1967. Electron microscopic observations of the equine parathyroid glands with particular reference to those of equine osteodystrophia fibrosa. Jpn. J. Vet. Res. 15: 37-71.

5. Kameda, Y, 1971. The occurrence and distribution of the parafollicular cells in the thyroid, parathyroid IV and thymus IV in some mammals. Arch, Histol. Jpn. 33: 283-299.

6. Kameda, Y. 1981. Destribution of C-cells in parathyroid gland IV and thymus IV of different mammals studied by immunoperoxidase method using anti-calcitonin and anti-C-thyroglobulin antisera. Kawasaki Med. J. 7: 97-111.

7. Kameda, Y. 1983. Immunohistochemical studies of thyroid parafollicular (C) cells. The Cell. 15: 38-46 (in Japanese).

8. Swarup, K., Srivastav, A. K., and Tewari, N. P. 1978. Occurrence of calcitonin cells and cysts in the parathyroid of the house shrew, Suncus muri- 
nus. Acta anat. 101: 340-345.

9. Tateyama, S., Nosaka, D., Monji, K., Tanimura, N., Moritomo, Y., and Cotchin, E. 1984. Application of anti-calcitonin antibody to masses of parafollicular cells in the equine thyroid glands. Jpn. J. Vet. Sci. (Suppl. 97): 95 (in Japanese).

10. Yanai, T., Tateyama, S., Nosaka, D., and Ashi- zawa, H. 1982. Some observations on the parafollicular (C) cells in the equine thyroid. Jpn.J. Vet. Sci. 44: 511-516.

11. Yoshikawa, T., Yoshikawa, H., Oyamada, T., and Suzuki, K. 1984. A follicular adenoma with C-cell hyperplasia in the equine thyroid. Jpn. J. Vet. Sci. 46: 615-623.

要 約

馬上皮小体に分布する荌滤胞細胞 ( $\mathrm{C}$ 細胞) の免疫組織化学的及び電子顕微鏡的㭘索：谷村信彦・立山 晉 ・ 野坂 大・森友靖尘 ${ }^{1)} \cdot$ 山口良二 (宮崎大学 農学部獣医学科 家玄病理学教室, ${ }^{1}$ 九州東海大学農学部) - 56 例 (41頭) の馬の上皮小体を $\mathrm{HE}$ 染色，抗ヒト・カルシトニン抗体による兒疫ペルオキシダーゼ染色及び電子顕微鏡 で観察した。C 細胞恃，免没染色陽性:分泌顆粒を満たし，42例の馬上皮小体に見出された。実質細胞は陰性であ った。上皮小体 $\mathrm{C}$ 細胞の形態と抗カルシトニン抗体感受性法, 馬甲状腺 $\mathrm{C}$ 細胞のそれとほほ录同じであった。 $\mathrm{HE}$ 染色では上皮小体 $\mathrm{C}$ 細胞は主細胞や水様透明細胞上りむエオジン好性であった。電顕像では，C細胞はいわゆる oxyphil cell と以明らか比異なり，種々の大きさの分泌顆粒多数を含み，実質細胞とともに基底膜によって間質 からは隔離され，ハーフデスモゾームで基底膜に接着し，デスモゾームで隣接細胞と接着していた。oxyphil cell とC 細胞間の移行型涊められなかった。免疫染色陽性のC 細胞怔，甲状腺に埋没した上皮小体において，遊離 上皮小体に抢けるよりむ出現頻度が高かった。馬の品種，年齢及び性別によるC 細胞出現頻度の差異は明瞭でな かった。 